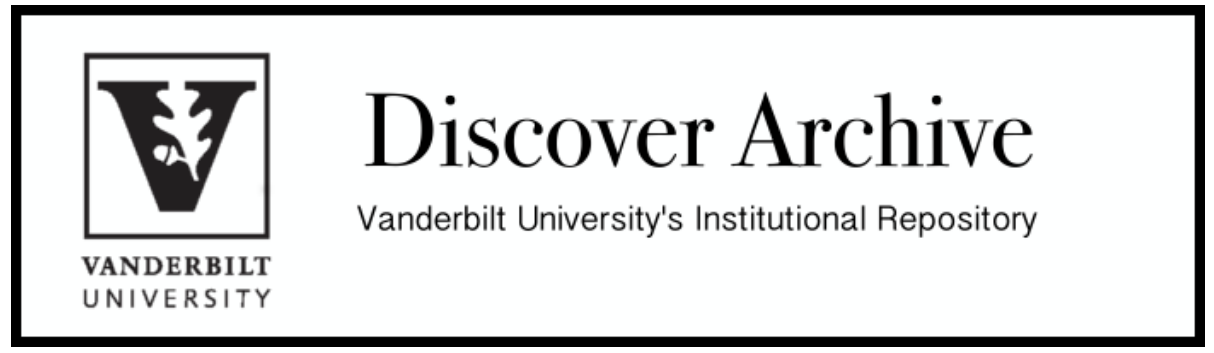

This article was originally published as:

Nancy J. King, Michael Heise, and Nicole A.Heise

\title{
State Criminal Appeals Revealed
}

70 Vanderbilt Law Review 1939 (2017) 


\section{HEINONLINE}

Citation:

Michael Heise; Nancy J. King; Nicole A. Heise, State

Criminal Appeals Revealed, 70 Vand. L. Rev. 1939

(2017)

Provided by:

Vanderbilt University Law School

Content downloaded/printed from $\underline{\text { HeinOnline }}$

Tue Feb 6 12:54:30 2018

-- Your use of this HeinOnline PDF indicates your acceptance of HeinOnline's Terms and Conditions of the license agreement available at http://heinonline.org/HOL/License

-- The search text of this PDF is generated from uncorrected OCR text.

-- To obtain permission to use this article beyond the scope of your HeinOnline license, please use:

\section{Copyright Information}

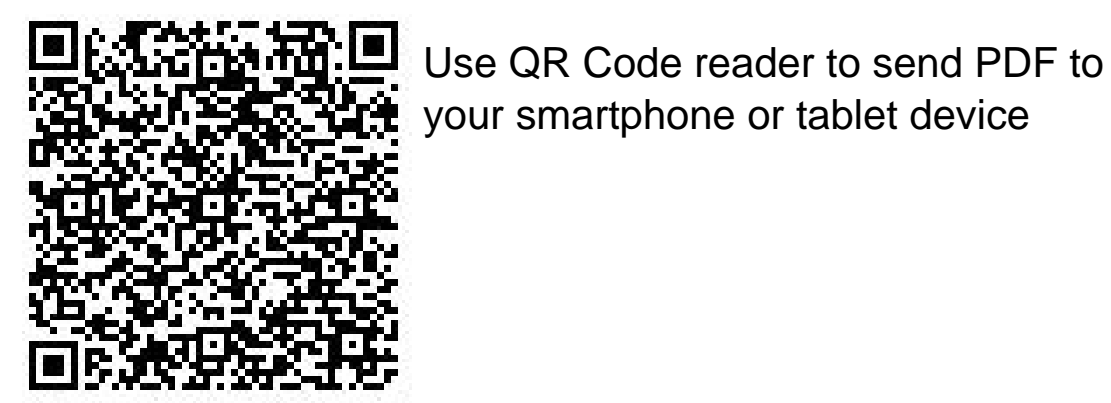




\title{
State Criminal Appeals Revealed
}

\author{
Michael Heise* \\ Nancy J. King** \\ Nicole A. Heise ${ }^{* * *}$
}

INTRODUCTION

I. PRIOR RESEARCH ON CRIMINAL APPEALS OUTCOMES....... 1941

II. Data, Methodology, AND ReSEARCh Design ............... 1944

A. Variables.................................................... 1948

1. Dependent Variables............................. 1948

2. Independent Variables ........................... 1949

a. Case and Claim Variables ............. 1949

b. Court Variables ............................. 1950

c. Appellate Process and Advocacy

Variables ...................................... 1951

III. RESULTS \& DISCUSSION ............................................ 1952

A. Descriptive Results ........................................ 1952

B. Regression Results .......................................... 1957

1. First Appeals of Right .......................... 1958

2. Courts of Last Resort ............................ 1961

C. Discussion ................................................. 1965

1. Comparison to Prior Studies ................... 1965

2. Sentencing Challenges and Sentencing Claims ................................................... 1965

3. Representation and Anders Briefs............ 1966

4. California and Florida Appeals ............... 1967

5. Crime Types Generally......................... 1968

6. Elected Judges, Oral Argument, Opinions, and Reply Briefs.................................... 1968

7. Claims Generally ................................. 1968

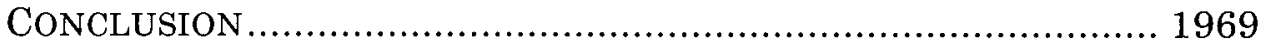

* Professor, Cornell Law School.

* Speir Professor, Vanderbilt University Law School.

*** A.B., 2013, Amherst College; J.D. Candidate, 2018, University of Chicago Law School. 


\section{INTRODUCTION}

Every state provides appellate review of criminal judgments, yet little research examines which factors correlate with favorable outcomes for defendants who seek appellate relief. ${ }^{1}$ To address this scholarly gap, this Article exploits the Survey of Criminal Appeals in State Courts (2010) dataset, recently released by the Bureau of Justice Statistics and the National Center for State Courts (hereinafter, "NCSC Study"). The NCSC Study is the first and only publicly available national dataset on state criminal appeals and includes unprecedented information from every state court in the nation with jurisdiction to review criminal judgments. ${ }^{2}$

Building upon prior research that we describe in Part I, our research design, described in Part II, focuses on two subpools of state criminal appeals: a defendant's first appeal of right, and defense appeals to courts of last resort with the discretion to grant or deny review. Error correction, of course, is paramount in the first context, for typically an appeal of right is a defendant's only chance at review. By contrast, courts of last resort with discretionary jurisdiction emphasize law development, selecting cases to clarify or alter legal rules, resolve conflicts, and remedy the most egregious mistakes. ${ }^{3}$ Given the critical differences between these two streams of appeals, we measure a defendant's "success" in distinct ways. For first appeals of right, we model a defendant's success in receiving a review on the merits and obtaining a favorable outcome. In the court of last resort setting, we model a defendant's success in terms of obtaining leave to appeal and, for those appeals granted review, obtaining a favorable outcome.

Our findings are presented in Part III and discussed in the Conclusion. Comparisons with existing studies imply that defense appellate success rates may have declined in recent decades. In appeals of right, defendants who challenge a sentence enjoy a greater likelihood of success, as do those who have legal representation, file a reply brief

1. See, e.g., Michael Heise, Federal Criminal Appeals: A Brief Empirical Perspective, 93 MARQ. L. REV. 825, 829 tbl.1 (2009) (finding 72\% of appeals involved sentence only, and an overall relief rate of 24\%); Jon O. Newman, A Study of Appellate Reversals, 58 BROOK. L. REV. 629, 63536 (1992) (19\% relief rate; $20 \%$ for sentencing-only challenges).

2. Survey of State Court Criminal Appeals, INTER-UNIVERSITY CONSORTIUM FOR POL. \& SOC. RES. (2010), https://www.icpsr.umich.edu/icpsrweb/ICPSR/studies/36465?q=36465 [https://perma.cc/BSC5-LDK2] [hereinafter Survey of State Court Criminal Appeals].

3. See Theodore Eisenberg et al., Israel's Supreme Court Appellate Jurisdiction: An Empirical Study, 96 CORNELL L. REV. 693 (2011) (studying the Israeli Supreme Court's reversal rates in mandatory and discretionary jurisdiction); Theodore Eisenberg \& Geoffrey P. Miller, Reversal, Dissent, and Variability in State Supreme Courts: The Centrality of Jurisdictional Source, 89 B.U. L. REV. 1451 (2009) (evaluating how state supreme court reversal rates and dissent patterns vary based on whether the court exercises discretionary or mandatory jurisdiction). 
or secure oral argument, and appellants from Florida. In high courts of last resort, appeals from sex offenses, raising certain trial issues, and appellants represented by publicly funded attorneys appear to fare better than others. Also notable is the absence of a relation between defense success and factors including most crime types and claims raised, the court's workload, and, for all but one model, whether the appellate judges were selected by election.

\section{PRIOR RESEARCH ON CRIMINAL APPEALs OUTCOMES}

We are aware of no other dataset that comes close to the NCSC Study in terms of depth and breadth. Most states have collected and published only disposition times and aggregate caseload information for criminal appeals (i.e., number of cases filed, pending, and disposed). The NCSC Study itself remains underexamined despite its public release. Two Bureau of Justice Statistics Bulletins report descriptive and preliminary information, often aggregating appeals from the two contexts that we study separately. ${ }^{4}$ While existing empirical research is limited, it nonetheless provides helpful methodological strategies and findings concerning the determinants of successful appeals.

National Center for State Courts' researchers Joyce Chapper and Roger Hanson authored the leading study on intermediate appellate court outcomes in 1989 . They collected data from nearly 1,750 first appeals of right filed by defendants and resolved between 1983 and 1985 in five states' courts, and reported defense success rates for specified claims, crime types, and types of representation. ${ }^{5}$ Chapper and Hanson found an overall defense win rate of approximately $20 \%$, coding

4. Nicole L. WATERS ET AL., U.S. DeP’T OF JUSTICE, NCJ 248874, CRIMiNAL APPEALS IN STATE COURTS (2015), https://www.bjs.gov/content/pub/pdf/casc.pdf [https://perma.cc/AAK358WR]; Nicole L. Waters \& Kathryn J. Gen'THON, NAT'L CTR. For STATE CoURTS, ACHIEviNG TIMELY RESOLUTTON FOR CRIMINAL APPEALS IN STATE COURTS (2016), https://cdm16501.contentdm.oclc.org/digital/collection/criminal/id/275 [https://perma.cc/FB5LTCBW]. The authors of a National Center for State Courts report in 2014 noted the aggregate disposition times from the Survey. See JoHn P. DOERnER, NAT'L CTR. FOR STATE COURTS, MODEL TIME STANDARDS FOR STATE APPELlaATE COURTS 11 (2014), https://ncsc.contentdm.oclc.org/digital/collection/appellate/id/1032 [https://perma.cc/J56D-4SWT] (reporting time to disposition and various interim events for intermediate courts and courts of last resort). Additional past literature focusing on the duration of appellate processes is collected in Roger A. HaNson, NAT'L Ctr. for State Courts, JuRisdiCtion, CaseloAd, AND Timeliness of

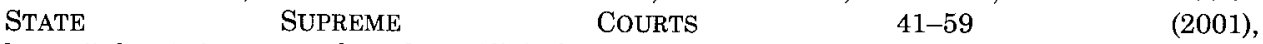
https://cdm16501.contentdm.oclc.org/digital/collection/appellate/id/58 [https://perma.cc/9J8ZZDUZ] (tracking the length of the appeal process in five state supreme courts, and any differences for death penalty cases in 1996 and 1997).

5. Joy A. Chapper \& Roger A. Hanson, NAT'L CTR. For State Courts, Understanding REVERSIBLE ERROR IN CRIMINAL APPEALS: FINAL REPORT (1989), https://cdm16501.contentdm.oclc.org/digital/collection/criminal/id/1 [https://perma.cc/39YSYJFK]. 
any outcome other than a complete affirmance or a dismissal as a decision favorable to the defense. ${ }^{6}$

Two more recent case studies also address intermediate court decisions in single states. Buller examined whether the type of representation for the defendant correlates with outcomes in 987 intermediate court criminal appeals in Iowa during 2012 and 2013 (including misdemeanor and postconviction appeals), finding $16.4 \%$ of all appeals were resolved in the defendant's favor. ${ }^{7}$ Foley found that $25 \%$ of defendants' direct appeals, but only $17 \%$ of defendants' postconviction appeals, resulted in corrections or reversals in the Tennessee Court of Criminal Appeals in the mid-1990s. ${ }^{8}$ He also found that more than half of the cases that involved corrections in favor of the defendant were sentencing errors and that "[t]he more serious the offense, the more likely the appellate court corrected the trial court judgment."

Researchers have devoted comparatively more attention to state courts of last resort. Kagan, Brace, and Hall collected data from approximately 21,000 high court decisions between 1995 and 1998. Although these data include parties, crime types, number of issues addressed, and several outcome options, they do not reveal which appeals were of right and which required leave to appeal, or which were postconviction appeals as opposed to direct appeals. ${ }^{10}$ More recently, Eisenberg and Miller created a dataset of 7,055 high court decisions

6. Id. at 5 tbl.1.

7. Tyler J. Buller, Public Defenders and Appointed Counsel in Criminal Appeals: The Iowa Experience, 16 J. APP. PraC. \& Process 183 app. C at 242 tbl.1 (2015).

8. Daniel J. Foley, The Tennessee Court of Criminal Appeals: A Study and Analysis, 66 TENN. L. REV. 427, 433 (1999). For earlier studies of a single state's intermediate court, see Thomas Y. Davies, Affirmed: A Study of Criminal Appeals and Decision-Making Norms in a California Court of Appeal, 82 AM. B. FOUND. RES. J. 543 (1982), which explores reversal rates in a California court of appeal, and DAvid T. WASsERMAN, A SwORD FOR THE CoNVICTED: REPRESENTING INDIGENT DEFENDANTS ON APPEAL (1990), which investigates criminal appeals in the appellate division of the New York State Supreme Court and the effects of defense representation. Both are cited in CHAPPER \& HANSON, supra note 5, at 28.

9. Foley, supra note 8 , at 435.

10. See Project Overview, ST. SuP. CT. DATA ProJECT, http://www.ruf.rice.edu/ pbrace/statecourt/ (last visited Sept. 22, 2017) [https://perma.cc/V9AJ$6 \mathrm{KXQ}]$. For older literature on state supreme courts using a sample of 5,904 cases decided by sixteen state supreme courts between 1870 and 1970, see Robert A. Kagan et al., The Business of State Supreme Courts, 1870-1970, 30 STAN. L. REV. 121 (1977), which tracks state supreme court caseloads, the types of cases they heard, and the sources of changes in the law, and Robert A. Kagan et al., The Evolution of State Supreme Courts, 76 MicH. L. REv. 961 (1978), which studies how state supreme courts adapted to rising caseloads. See also Project, The Effect of Court Structure on State Supreme Court Opinions: A Re-Examination, 33 STAN. L. REV. 951, 957 tbl.1 (1981) (reporting criminal "win rates" between $20 \%$ and $61 \%$ for four different state supreme courts in the late 1970s); Note, Courting Reversal: The Supervisory Role of State Supreme Courts, 87 YALE L.J. 1191 (1978) (evaluating how state supreme courts supervise lower state courts). 
from 2003 published on Westlaw. 11 They found reversal rates of $49 \%$ for noncapital criminal cases accepted for review when appeal required permission and $28 \%$ for cases appealed of right, rates that varied by state and type of issue (evidence, procedure, sentence, or substance), but not by filings per justice or whether the court sat en banc. ${ }^{12}$

The State Courts Statistics Project ("the Project") also contributes helpful data on state criminal appeals. Over the past few years, states have started to collect and report appeals information to the Project, including: whether the appeal was by right or by permission; whether it involved a capital, felony, or misdemeanor case; whether it was from a criminal judgment or a postconviction decision; whether it involved merits review or dismissal; and, for appeals by permission, whether leave to appeal was denied..$^{13}$ Although these data, available online, include whether a merits disposition was an affirmance or something else (reversal/remand), they do not reveal which party appealed. As a result, the data include no reliable measure of defense relief rates. ${ }^{14}$ Moreover, such variables as the crime of conviction, nature of defense representation, and other case details were also not collected.

We used the existing empirical literature to inform our statistical models. Unfortunately, prior studies include limitations that complicate efforts to compare findings across various studies. Many, for example, do not account for important variations in appellate structure or distinguish between appeals of right and permissive appeals. ${ }^{15}$ Some studies included interlocutory appeals, appeals of capital case judgments, probation or parole revocations, civil commitments, orders

11. Eisenberg \& Miller, supra note 3, at 1454 .

12. Id. at 1474-75 fig.1, 1497; see also Eisenberg et al., supra note 3, at 694 (noting "the importance of distinguishing between mandatory and discretionary jurisdiction in analyzing appellate court behavior").

13. About the Court Statistics Project, CT. STAT. PROJECT, http://www.courtstatistics.org/ (last visited Sept. 22, 2017) [https://perma.cc/CJ5Q-AVEB]. The reporting guide notes that merits resolutions exclude transfers, dismissals before opinion, and "Court ADR." Reversals are any disposition other than nonmerits resolution or complete affirmance. See CoURT STATISTICS Project, Nat'L CTr. For State Courts, State Court Gumb to STATISTiCal Reporting 60 (2017), http://www.courtstatistics.org/ /media/Microsites/Files/CSP/State\%20Court\%20Guide\% 20to\%20Statistical\%20Reporting\%20v\%202point1point2.ashx [https:/perma.cc/PAA8-6X36] [hereinafter STATE COURT GUDE].

14. STATE CoURT GUIDE, supra note 13 , at 39-61.

15. See, e.g., Eisenberg \& Miller, supra note 3, at 1464 (noting that Brace and Hall's fiftystate study of courts of last resort did not make this distinction). 
denying postconviction relief, ${ }^{16}$ and cases associated with rates of relief that differ from direct criminal appeals. ${ }^{17}$

\section{Data, Methodology, AND RESEARCh DESIGN}

Data in the NCSC Study appear in two separate though related datasets. The main dataset includes information from a nationally representative probability sample of criminal appeals resolved in 2010 by the fifty-one courts of last resort and ninety-two intermediate appellate courts in the United States that have criminal jurisdiction. Criminal appeals that involved juveniles, postconviction proceedings, interlocutory appeals, probation or parole revocations, or civil commitments were not included.18 The oversample dataset includes information drawn from a second sample, also random and using the same criteria for inclusion as the main dataset, except for one difference: all appeals in the oversample dataset involved last resort appeals reviewing decisions of intermediate appellate courts. To increase the number of last resort cases for our analyses, we added the 272 last resort cases from the oversample dataset to the cases in the main dataset. To better align our research questions to the available data and avoid potential distortion, we excluded three categories of cases from our combined sample: 137 capital cases, 162 state-initiated appeals, and 433 misdemeanor appeals, keeping only appeals from felony judgments. ${ }^{19}$

Our research questions prompted further filtering for the regression analyses. In contrast to some studies that combine decisions of intermediate and last resort courts, as well as discretionary and mandatory appeals, we explored factors related to outcome in two different contexts: a defendant's first appeal of right, and review by a

16. Chapper and Hanson's findings, for example, involved appeals of all of the following combined: criminal judgments, denials of postconviction relief, and probation and parole revocations, as well as criminal contempt and bail rulings. See CHAPPER \& HANSON, supra note 5, at 4 .

17. For example, postconviction appeals are generally less likely to produce relief for a defendant than direct appeals. See Nancy J. King, Enforcing Effective Assistance After Martinez, 122 YALE L.J. 2428 (2013) (collecting estimates of success rates in noncapital state postconviction proceedings).

18. For a general description of the appeals dataset, see Survey of State Court Criminal Appeals, supra note 2. See also WATERS ET AL., supra note 4, at 10 (describing the methodology of the 2010 dataset). Note that the courts of last resort for noncapital felony appeals in Oklahoma and Texas are the states' courts of criminal appeals, not the states' supreme courts.

19. These appeals raise unique issues and generate different relief rates. See, e.g., Rosanna Cavallaro, Better Off Dead: Abatement, Innocence, and the Evolving Right of Appeal, 73 U. CoLO. L. REV. 943, 977-78 (2002) (collecting authority finding higher rates of appellate relief for capital cases). But see Eisenberg \& Miller, supra note 3 , at 1474 (finding, in study of court of last resort appeals only, slightly lower reversal rates for capital cases than noncapital cases). 
court of last resort that had discretion to accept or reject a defendant's appeal. The large number of appeals in the NCSC Study allowed us to analyze the two subpools separately. ${ }^{20}$

The "first appeal of right" subpool includes appeals that were decided by: (1) intermediate appellate courts where review was mandatory; and (2) courts of last resort in nine states where, in 2010, there was no intermediate court and review in criminal cases was mandatory. We excluded from this subpool appeals that required leave to appeal, including all of the cases from Virginia, a state that provides only discretionary review in criminal cases, and guilty plea appeals in Michigan, also discretionary only. ${ }^{21}$ The "discretionary-last-resort" subpool includes appeals decided by courts of last resort that had the discretion to deny review. ${ }^{22}$ From both subpools, we also excluded appeals from three states (Idaho, Iowa, and Mississippi) that employ the unique "deflective" appellate structure. ${ }^{23}$

In all, as Table 1 indicates, our final dataset includes 3,505 defendant-initiated direct appeals, including 2,080 first appeals of right and 1,425 discretionary appeals to courts of last resort. Table 1 also reports the distribution of decisions favoring the defendant and other important variations across states.

20. Data in the NCSC Study indicated whether appellate jurisdiction in each case was mandatory or discretionary, and we independently confirmed these classifications with research into state law.

21. See Halbert v. Michigan, 545 U.S. 605, 632 (2005) (only discretionary review for appeals from guilty plea convictions in Michigan); WATERS ET AL., supra note 4, at 7 (discretionary jurisdiction for Virginia's intermediate appellate court and court of last resort for the majority of their caseloads). In the main dataset, of Virginia Court of Appeals cases $(\mathrm{N}=113$ ), only $2.7 \%$ produced a decision favorable to the defendant. In the Michigan Court of Appeals, only $9.3 \%$ of discretionary appeals $(\mathrm{N}=6)$ produced a decision favorable to the defendant.

22. This set was almost entirely cases in states with intermediate courts, except for West Virginia and New Hampshire, where each has only one appellate court, and in 2010 their review was discretionary. We excluded the small number of appeals that had been transferred from an intermediate appellate court to a state's court of last resort $(\mathrm{N}=22)$.

23. $\mathrm{N}=84$. All appeals are filed in the state supreme courts, which retain some and transfer the remainder to their respective intermediate courts. See WATERS ET AL., supra note 4, at 2 map 1 (classifying states into seven patterns as of 2010). 
TABLE 1: SUMMARY OF CRIMINAL APPEALS AND DEFENDANT APPELLATE SUCCESS, BY STATE

\begin{tabular}{|c|c|c|c|c|c|c|c|}
\hline & $\begin{array}{l}\text { Total } \\
\text { from } \\
\text { state }\end{array}$ & $\begin{array}{c}1^{\text {st }} \\
\text { appeal } \\
\text { of-right }\end{array}$ & $\begin{array}{l}\text { Last resort } \\
\text { appeal, } \\
\text { discretion }\end{array}$ & $\begin{array}{l}\% \text { Total } \\
\text { sample } \\
\text { from } \\
\text { state }\end{array}$ & $\begin{array}{l}1^{\text {st }} \text { appeal } \\
\text { decision } \\
\text { fav. def. } \\
(\%)\end{array}$ & $\begin{array}{c}\text { Last } \\
\text { resort } \\
\text { decision } \\
\text { fav. def. } \\
\text { (all } \\
\text { cases) } \\
(\%)\end{array}$ & $\begin{array}{c}\text { Last } \\
\text { resort } \\
\text { decision } \\
\text { fav. def. } \\
\text { (granted } \\
\text { cases) } \\
(\%)\end{array}$ \\
\hline$[T t l]$ & 3,505 & 2,080 & $1, \overline{425}$ & - & 14.9 & 2.8 & 44.9 \\
\hline $\mathrm{AK}$ & 10 & 6 & 4 & 0.29 & 16.7 & 25.0 & 100.0 \\
\hline $\mathrm{AL}$ & 42 & 26 & 16 & 1.20 & 19.2 & 12.5 & 50.0 \\
\hline $\mathrm{AR}$ & 14 & 14 & 0 & 0.40 & 0.0 & - & - \\
\hline $\mathrm{AZ}$ & 37 & 34 & 3 & 1.06 & 11.8 & 33.3 & 100.0 \\
\hline $\mathrm{CA}$ & 882 & 311 & 571 & 25.16 & 19.3 & 0.4 & 12.5 \\
\hline $\mathrm{CO}$ & 38 & 21 & 17 & 1.08 & 28.6 & 5.9 & 100.0 \\
\hline $\mathrm{CT}$ & 5 & 5 & 0 & 0.14 & 20.0 & - & - \\
\hline DC & 42 & 42 & 0 & 1.20 & 16.7 & - & - \\
\hline $\mathrm{DE}$ & 7 & 7 & 0 & 0.20 & 0.0 & - & - \\
\hline FL & 265 & 260 & 5 & 7.56 & 10.4 & 0.0 & 0.0 \\
\hline GA & 28 & 25 & 3 & 0.80 & 4.0 & 33.3 & 33.3 \\
\hline $\mathrm{HI}$ & 10 & 2 & 8 & 0.29 & 0.0 & 37.5 & 100.0 \\
\hline IL & 86 & 73 & 13 & 2.45 & 19.2 & 7.7 & 50.0 \\
\hline IN & 52 & 36 & 16 & 1.48 & 8.3 & 0.0 & - \\
\hline KS & 4 & 3 & 1 & 0.11 & 0.0 & 100.0 & 100.0 \\
\hline $\mathrm{KY}$ & 40 & 30 & 10 & 1.14 & 36.7 & 60.0 & 100.0 \\
\hline LA & 79 & 40 & 39 & 2.25 & 32.5 & 0.0 & - \\
\hline MA & 47 & 44 & 3 & 1.34 & 34.1 & 100.0 & 100.0 \\
\hline MD & 35 & 25 & 10 & 1.00 & 16.0 & 10.0 & 100.0 \\
\hline $\mathrm{ME}$ & 2 & 2 & 0 & 0.06 & 0.0 & - & - \\
\hline MI & 75 & 38 & 37 & 2.14 & 10.5 & 5.4 & 100.0 \\
\hline $\mathrm{MN}$ & 56 & 22 & 34 & 1.60 & 4.6 & 0.0 & - \\
\hline MO & 19 & 15 & 4 & 0.54 & 13.3 & 25.0 & 100.0 \\
\hline
\end{tabular}




\begin{tabular}{|c|c|c|c|c|c|c|c|}
\hline & $\begin{array}{l}\text { Total } \\
\text { from } \\
\text { state }\end{array}$ & $\begin{array}{c}1^{\text {st }} \\
\text { appeal } \\
\text { of-right }\end{array}$ & $\begin{array}{l}\text { Last resort } \\
\text { appeal, } \\
\text { discretion }\end{array}$ & $\begin{array}{l}\% \text { Total } \\
\text { sample } \\
\text { from } \\
\text { state }\end{array}$ & $\begin{array}{l}1^{\text {st }} \text { appeal } \\
\text { decision } \\
\text { fav. def. } \\
\text { (\%) }\end{array}$ & $\begin{array}{c}\text { Last } \\
\text { resort } \\
\text { decision } \\
\text { fav. def. } \\
\text { (all } \\
\text { cases) } \\
(\%)\end{array}$ & $\begin{array}{c}\text { Last } \\
\text { resort } \\
\text { decision } \\
\text { fav. def. } \\
\text { (granted } \\
\text { cases) } \\
(\%)\end{array}$ \\
\hline MT & 6 & 6 & 0 & 0.17 & 33.3 & - & - \\
\hline $\mathrm{NC}$ & 30 & 21 & 9 & 0.86 & 42.9 & 0.0 & - \\
\hline ND & 8 & 8 & 0 & 0.23 & 0.0 & - & - \\
\hline $\mathrm{NE}$ & 15 & 15 & 0 & 0.43 & 0.0 & - & - \\
\hline $\mathrm{NH}$ & 10 & 0 & 10 & 0.29 & - & 10.0 & 10.0 \\
\hline NJ & 116 & 112 & 4 & 3.31 & 12.5 & 0.0 & 0.0 \\
\hline NM & 24 & 13 & 11 & 0.68 & 30.8 & 0.0 & - \\
\hline NV & 25 & 25 & 0 & 0.71 & 16.0 & - & - \\
\hline NY & 194 & 92 & 102 & 5.53 & 12.0 & 1.0 & 100.0 \\
\hline $\mathrm{OH}$ & 251 & 180 & 71 & 7.16 & 25.6 & 1.4 & 33.3 \\
\hline OK & 10 & 10 & 0 & 0.29 & 10.0 & - & - \\
\hline OR & 70 & 31 & 39 & 2.00 & 6.5 & 2.6 & 33.3 \\
\hline PA & 245 & 149 & 96 & 6.99 & 6.0 & 0.0 & 0.0 \\
\hline RI & 2 & 2 & 0 & 0.06 & 0.0 & - & - \\
\hline $\mathrm{SC}$ & 11 & 6 & 5 & 0.31 & 0.0 & 0.0 & - \\
\hline SD & 6 & 6 & 0 & 0.17 & 16.8 & - & - \\
\hline TN & 51 & 31 & 20 & 1.46 & 12.9 & 10.0 & 100.0 \\
\hline $\mathrm{TX}$ & 268 & 185 & 83 & 7.65 & 3.8 & 2.41 & 50.0 \\
\hline UT & 8 & 4 & 4 & 0.23 & 0.0 & 0.0 & 0.0 \\
\hline VA & 144 & 0 & 144 & 4.11 & - & 2.8 & 66.7 \\
\hline VT & 3 & 3 & 0 & 0.09 & 0.0 & - & - \\
\hline WA & 78 & 52 & 26 & 2.23 & 30.1 & 3.9 & 100.0 \\
\hline WI & 39 & 39 & 0 & 1.11 & 0.0 & - & - \\
\hline WV & 7 & 0 & 7 & 0.20 & - & 14.3 & 50.0 \\
\hline WY & 9 & 9 & 0 & 0.26 & 0.0 & - & - \\
\hline
\end{tabular}




\section{A. Variables}

\section{Dependent Variables}

Our analyses investigate three dependent variables, reflecting different stages in the appellate process. Our two models of first appeals of right explore factors associated with (1) review of the merits rather than dismissal or withdrawal, and (2) a decision favorable to the defendant. Our two models of discretionary last resort appeals examine factors associated with (1) a decision to grant review; and, for those appeals granted review, (2) a decision favorable to the defendant. We defined a decision as favoring the defendant if it involved anything other than an affirmance, a dismissal, a denial of review, or a withdrawal. It is worth noting that our coding convention captures many decisions that a defendant might not necessarily consider to be a "win," including remands and modest modifications of one of several sentences. The data do not offer a reliable method to distinguish significant modifications or remands from less meaningful ones, and the approach we take comports with prior empirical work examining appeals. ${ }^{24}$ Table 2 presents a descriptive summary of our dependent variables.

Table 2: Review Granted, Merits Review, Favorable Decision, By COURT

\begin{tabular}{|c|c|c|c|}
\hline & $\begin{array}{l}\text { Defendant granted } \\
\text { review (\%) }\end{array}$ & $(\mathrm{N})$ & (total) \\
\hline \multirow[t]{2}{*}{$\begin{array}{l}\text { Last resort discretionary, of all cases } \\
\text { filed }\end{array}$} & 6.3 & 89 & 1,425 \\
\hline & $\begin{array}{l}\text { Defendant received } \\
\text { merits review (\%) }\end{array}$ & $(\mathrm{N})$ & (total) \\
\hline \multirow{3}{*}{$\begin{array}{l}\text { First appeal of right, of all cases filed } \\
\text { Last resort discretionary, of all cases } \\
\text { filed }\end{array}$} & 90.3 & 1,879 & 2,080 \\
\hline & 4.6 & 65 & 1,425 \\
\hline & $\begin{array}{c}\text { Decision favored } \\
\text { defendant }(\%)\end{array}$ & $(\mathrm{N})$ & (total) \\
\hline First appeal of right, of all cases filed & 14.9 & 309 & 2,080 \\
\hline $\begin{array}{l}\text { Last resort discretionary, of all cases } \\
\text { filed }\end{array}$ & 2.8 & 40 & 1,425 \\
\hline $\begin{array}{l}\text { Last resort discretionary, of all cases } \\
\text { granted review }\end{array}$ & 44.9 & 40 & 89 \\
\hline
\end{tabular}

SOURCE: Survey of State Court Criminal Appeals, supra note 2.

24. See, e.g., CHAPPER \& HANSON, supra note 5, at 5; Theodore Eisenberg \& Michael Heise, Plaintiphobia in State Courts Redux? An Empirical Study of State Court Trials on Appeal, $12 \mathrm{~J}$. EMPIRICAL LEGAL STUD. 100, 115 n.72 (2015). 


\section{Independent Variables}

Our independent variables fall into three broad groups: (1) the types of crimes for conviction and claims raised on appeal, (2) court factors, and (3) factors incident to advocacy or the appellate process.

\section{a. Case and Claim Variables}

Crime type. A defendant's offense may influence the likelihood of obtaining relief on appeal. ${ }^{25}$ We collapsed the twenty-three crime types into ten broader crime types that roughly track groupings from other studies ${ }^{26}$ and created a dummy variable for each. Where descriptive analyses indicated that related crime types generated quite different rates of relief for defendants, however, we maintained the distinctive underlying crime types.

Appeal from sentence or conviction. Because sentencing errors typically require only resentencing or recalculation to correct, we anticipated that sentence challenges would generate a higher rate of success than conviction-only challenges. ${ }^{27}$ From data that specify whether the defendant is appealing the sentence, the conviction, both, or unknown, ${ }^{28}$ we created two dummy variables: one for appeals that include a challenge to a sentence and another for appeals that challenge only a conviction.

Claim included in brief. Our descriptive analyses and prior research suggested that some claims are more likely than others to generate a favorable decision for a defendant. ${ }^{29} \mathrm{We}$ combined the fortynine claim categories from the NCSC Study into eleven broader categories of claims: (1) charge related, including statutory interpretation and venue; (2) plea related; (3) discovery and disclosure, including prosecutorial misconduct; (4) suppression issues; (5) other pretrial error, including double jeopardy and delay; (6) evidentiary

25. See, e.g., CHAPPER \& HANSON, supra note 5, at 36 (finding lower modification rates of violent crime convictions).

26. See, e.g., E. ANN CARSON \& WILLIAM J. SABOL, U.S. DEP'T OF JUSTICE, NCJ 248766, AGING OF THE STATE PRISON POPULATION, 1993-2013, at 16 (2016), https://www.bjs.gov/content/pub/pdf/aspp9313.pdf [https://perma.cc/G6GE-DYL7].

27. WATERS ET AL., supra note 4, at 6 fig. 3 (finding the rate of success is higher for sentencing claims than for other sorts of claims among claims addressed in written opinions); see also Buller, supra note 7, at 196-97; Foley, supra note 8, at 432, 435-36, 454 tbl.6 (finding sentence modifications are more common than conviction corrections in Tennessee appellate courts).

28. The aspect of the judgment challenged on appeal was available for $91 \%$ of first appeals of right and $76 \%$ of those granted review by courts of last resort, but was missing from most of the discretionary last resort cases denied review. See infra Table 3. For first appeals of right, $18 \%$ were sentence-only challenges and $25 \%$ challenged both sentence and conviction.

29. See, e.g., CHAPPER \& HANSON, supra note 5 , at 42 (finding defense win rate varies by issue). 
issues other than suppression, including confrontation and experts; (7) claims of insufficient evidence; (8) challenges to judge or jury selection, bias, management, or instruction; (9) other trial error, including competency, interpreters, mistrial, and joinder issues; (10) sentencing error; and (11) counsel-related errors, including ineffective assistance claims. ${ }^{30}$

\section{b. Court Variables}

State related. Results in Table 1 emphasize the need to recognize important variations across states, including success rates. To better account for the possibility that appeal outcomes within a state are not independent of one another, we clustered our analyses at the state level. Because California accounted for $40 \%$ of our sample of discretionary last resort cases, our analyses of that subpool explore whether California appeals systematically differed from appeals from other states. In the models examining first appeals of right, we controlled for the two states with more than $10 \%$ of that subpool: California $(15 \%)$ and Florida (13\%).

Judicial selection. In light of research suggesting that elected judges are less likely than appointed judges to side with criminal defendants, ${ }^{31}$ we created a dummy variable signaling whether a state's initial judicial selection method for the relevant court involved any form of election rather than appointment. ${ }^{32}$

Court workload. Some prior research suggests that courts devote more time and resources when reversing a decision made by a lower court than when affirming, which suggests that higher caseloads could depress the rate of reversals. ${ }^{33}$ That is, if reversals are more labor- and time-intensive than affirmances for appellate judges, appellate courts facing comparatively higher caseload pressures may be less inclined to

30. Like information about which aspect of the judgment was challenged on appeal, claims information was missing from most of the appeals in the discretionary-last-resort subpool that were denied leave, but not from the appeals accepted for review. The NCSC Study also coded claims addressed in cases that had opinions, but because these values were missing from so many more cases, such as first appeals of right resolved by summary order as well as from discretionarylast-resort cases denied review, we opted to use whether the claim was raised in the defendant's brief.

31. See Michael S. Kang \& Joanna M. Shepherd, Judging Judicial Election, 114 MICH. L. REv. 929 (2016).

32. See State Court Org., Selection of Appellate Court Judges, NAT'L CTR. FOR ST. CTS., http://data.ncsc.org/QvAJAXZfc/opendoc.htm?document=Public\%20App/SCO.qvw\&host=QVS@qli kviewisa\&anonymous=true\&bookmark=Document $\backslash$ BM86 (last visited Sept. 22, 2017) [https://perma.cc/XSA9-N6TZ].

33. See also Bert I. Huang, Lightened Scrutiny, 124 HARV. L. REv. 1109 (2011) (finding fewer reversals associated with caseload increases in federal courts). 
reverse, at least at the margins. We calculated for each court a continuous variable measuring workload by dividing the total appellate filings in each court ${ }^{34}$ by the number of judges or justices on that particular court. ${ }^{35}$

\section{c. Appellate Process and Advocacy Variables}

Defense counsel. We anticipated that: (1) pro se defendants would fare comparatively worse than represented defendants; and (2) retained counsel would perform better than publicly funded counsel, in part because losing cases are less likely to be pursued when the defendant is paying. ${ }^{36}$ To investigate these possibilities we created three separate dummy variables that signal the presence of pro se, publicly funded, and private attorney representation, respectively.

Anders briefs, reply briefs, oral argument, and full opinions. We expected that when defense lawyers filed an Anders or Wende brief, or a similar statement that no meritorious issues existed, defendants would succeed less frequently than when such concessions were not made, as simple comparisons suggested. ${ }^{37} \mathrm{We}$ also expected, and comparisons showed, that appellants who filed replies were more likely to succeed on appeal than those who did not, as were those allowed to make an oral argument. The presence of an oral argument not only provides a defendant with an additional opportunity to advocate, but granting oral argument could also signal the court's perception of the

34. We used 2012 caseloads from the Court Statistics Project, since 2010 caseload data were not available for every state. See State Court Caseload Statistics, CT. STAT. PROJECT, http://www.courtstatistics.org/Other-Pages/StateCourtCaseloadStatistics.aspx (last visited Oct. 27, 2017) [https://perma.cc/RB22-NKRP].

35. For judges per court, see State Court Org., Number of Appellate Court Judges, NAT'L CTR. FOR ST. CTS., http://data.ncsc.org/QvAJAXZfc/opendoc.htm?document=Public\%20App/ SCO.qvw\&host=QVS@qlikviewisa\&anonymous=true\&bookmark=Document $\backslash B M 82$ (last visited Oct. 27, 2017) [https://perma.cc/939X-WZMZ].

36. See, e.g., Buller, supra note 7, at 210-11, 220 (Privately retained counsel obtained favorable action in $22 \%$ of their cases compared to $19.38 \%$ for appellate defenders, but defenders won dismissal or acquittal of at least one count of conviction in $3.7 \%$ of cases compared to retained counsel's $2.4 \%$, and for sentencing issues, defenders succeeded in $9.5 \%$ of cases compared to retained attorneys' $7.3 \%$. Court-appointed counsel were consistently worse than defenders or retained counsel in all categories.). Unfortunately, the NCSC Study did not include information on the type of publicly funded counsel-public defender or appointed. The information about representation was missing from most of the discretionary appeals to courts of last resort that were denied review. See infra Table 3. The NCSC researchers suggested to us that these missing values likely reflect the inability to determine whether the attorney listed for the appellant was retained or publicly funded.

37. On Anders rules generally, see WAYNE R. LAFAVE ET AL., 3 CRIMINAL PROCEDURE $\S 11.2$ (c) (4th ed. 2015) and James E. Duggan \& Andrew W. Moeller, Make Way for the ABA: Smith v. Robbins Clears a Path for Anders Alternatives, 3 J. APP. PRAC. \& PROCESS 65 (2001). 
appeal's importance or merit. ${ }^{38} \mathrm{~A}$ similar signal is provided by the court's decision to produce a full judicial opinion. Also, a full opinion may be more common when the decision being appealed by the defendant is reversed, as it provides an opportunity for judicial explanation. Our analyses include dummy variables for each of these features.

\section{RESULTS \& DISCUSSION}

\section{A. Descriptive Results}

Tables 2 and 3 illustrate the impact of case selection by courts of last resort. Compared to decisions by courts required to consider every appeal, Column 2 in Table 2 illustrates that where defendants received a favorable decision $14.9 \%$ of the time, defendants' success rate dropped to $2.8 \%$ in discretionary courts of last resort. ${ }^{39}$ Column 4 in Table 3 reports results for the small number of appeals that courts of last resort selected for review. Among those cases granted review, defendant success jumped to $44.9 \%$. These findings are consistent with prior research confirming systematic differences between results in the mandatory and discretionary appeal contexts.

Table 3 also reports basic information about the small subset of cases granted review in courts of last resort. Among appeals receiving review that had information about the aspect of judgment contested, more than one-half (55.1\%) involved a defendant's appeal from an underlying conviction. In terms of crime types, courts of last resort agreed to review a higher rate of appeals from sex and drug trafficking convictions $(20.2 \%$ and $19.1 \%$, respectively) than appeals involving other crimes (between 1.1\% and 13.5\%). Fewer than one-half (47.2\%) of the cases granted review by courts of last resort included oral argument, and about $39.3 \%$ lacked a full written judicial opinion.

For first appeals of right, Table 3 reveals that sentencing and insufficient evidence claims are the most common claims raised $(29.9 \%$ and $28.9 \%$, respectively), that about half $(48.4 \%)$ of the cases challenged conviction alone, and about half (55.6\%) involved convictions for violent offenses (homicide, sex, robbery, or assault). Only approximately one in five (19.1\%) of right appeals included oral argument, about one in four (26.3\%) had a reply brief, and almost half (44\%) lacked a full opinion. Publicly appointed counsel outnumbered retained counsel ten to one

38. See Foley, supra note 8 , at 444 (the prosecution prevailed in $83 \%$ of cases submitted solely in briefs but only in $61 \%$ of cases submitted on oral argument).

39. See note 21 for rates of favorable decisions for discretionary first-level appeals in Virginia and Michigan. 
(73\% and $7 \%$ respectively), with only $5 \%$ of defendants appealing pro se.

Notably, a greater portion of first appeals of right (90\%) were heard on the merits than appeals granted review by courts of last resort (73\%). A further examination of the twenty-four cases accepted for review but not decided on the merits in courts of last resort revealed that one-half (twelve) were withdrawn and, of those not formally withdrawn, five $(20.8 \%)$ were dismissed for procedural error, three $(12.5 \%)$ for no valid issue on appeal, three $(12.5 \%)$ for lack of jurisdiction, and one (4.2\%) for leave improvidently granted. It is not clear whether any of those withdrawn appeals granted review involved or reflected settlement activity.

Anders-type briefs or statements appeared in a little more than one of every ten (11\%) first appeals of right, but in none of the discretionary last resort appeals. About $47 \%$ of the first appeals of right were heard by courts where the bench was elected, compared to $35 \%$ of the discretionary appeals decided by courts of last resort.

TABLE 3: SUMMARY OF KEY VARIABLES

\begin{tabular}{|c|c|c|c|c|}
\hline & $\begin{array}{c}\text { (1) } \\
\% \text { of all } \\
\text { appeals }\end{array}$ & $\begin{array}{c}\text { (2) } \\
\% \text { of first } \\
\text { level of- } \\
\text { right cases }\end{array}$ & $\begin{array}{c}(3) \\
\% \text { of all } \\
\text { last resort } \\
\text { cases }\end{array}$ & $\begin{array}{c}(4) \\
\% \text { of last } \\
\text { resort } \\
\text { cases } \\
\text { granted rev. }\end{array}$ \\
\hline \multicolumn{5}{|l|}{ Dependent Variables: } \\
\hline $\begin{array}{l}\text { Def. received merits } \\
\text { review }\end{array}$ & 55.5 & 90.3 & 4.6 & 73.0 \\
\hline $\begin{array}{l}\text { Def. granted leave to } \\
\text { appeal }\end{array}$ & - & - & 6.3 & - \\
\hline $\begin{array}{l}\text { Decision favored defendant } \\
\text { Independent Variables: } \\
\text { Appeal from: }\end{array}$ & 10.0 & 14.9 & 2.8 & 44.9 \\
\hline Conviction (alone) & 34.8 & 48.4 & 14.9 & 55.1 \\
\hline Sentence (included) & 31.0 & 42.6 & 14.0 & 25.8 \\
\hline (unknown/missing) & 34.2 & 9.0 & 71.1 & 19.1 \\
\hline \multicolumn{5}{|l|}{ Crime type: } \\
\hline Murder/vol. manslaughter & 13.9 & 14.4 & 13.1 & 13.5 \\
\hline Sex offense & 12.6 & 13.6 & 11.2 & 20.2 \\
\hline Robbery & 9.8 & 11.1 & 8.1 & 12.4 \\
\hline Assault & 14.1 & 16.5 & 10.6 & 5.6 \\
\hline Burglary & 4.9 & 6.3 & 2.7 & 2.3 \\
\hline Larceny, fraud, other prop. & 6.9 & 8.2 & 4.9 & 4.5 \\
\hline Drug trafficking & 11.2 & 13.6 & 7.6 & 19.1 \\
\hline Drug possession & 5.0 & 5.6 & 4.1 & 9.0 \\
\hline Public order & 7.1 & 8.7 & 4.8 & 2.3 \\
\hline Court order violation & 1.3 & 1.3 & 1.3 & 1.1 \\
\hline (unknown felony) & 13.3 & 0.7 & 31.6 & 10.1 \\
\hline
\end{tabular}




\begin{tabular}{|c|c|c|c|c|}
\hline & $\begin{array}{c}(1) \\
\% \text { of all } \\
\text { appeals }\end{array}$ & $\begin{array}{c}(2) \\
\% \text { of first } \\
\text { level of- } \\
\text { right cases }\end{array}$ & $\begin{array}{c}\text { (3) } \\
\% \text { of all } \\
\text { last resort } \\
\text { cases }\end{array}$ & $\begin{array}{c}\text { (4) } \\
\% \text { of last } \\
\text { resort } \\
\text { cases } \\
\text { granted rev. }\end{array}$ \\
\hline \multicolumn{5}{|l|}{ Claim included in brief: } \\
\hline Charge, statute, venue & 6.2 & 9.6 & 1.2 & 9.0 \\
\hline Plea related & 4.6 & 7.5 & 0.3 & 0.0 \\
\hline Other pretrial & 6.6 & 10.4 & 1.1 & 11.2 \\
\hline Discovery, prosec. miscon. & 5.8 & 9.3 & 0.7 & 5.6 \\
\hline Evidence suppression & 8.6 & 13.4 & 1.5 & 21.3 \\
\hline Insufficient evidence & 18.1 & 28.9 & 2.4 & 18.0 \\
\hline Other evidence, confront. & 12.5 & 20.1 & 1.4 & 13.5 \\
\hline Judge, jury & 10.9 & 17.4 & 1.4 & 14.6 \\
\hline Other trial issue & 7.8 & 12.4 & 1.1 & 12.4 \\
\hline Sentence & 18.3 & 29.9 & 1.4 & 4.5 \\
\hline Counsel & 7.7 & 12.5 & 0.6 & 5.6 \\
\hline (claims raised unknown) & 47.1 & 15.6 & 93.2 & 33.7 \\
\hline \multicolumn{5}{|l|}{ Court factors: } \\
\hline Elected judges & 41.7 & 46.6 & 34.7 & 37.1 \\
\hline CA state & 25.2 & 15.0 & 40.1 & 18.0 \\
\hline \multicolumn{5}{|l|}{ Process \& advocacy factors: } \\
\hline Oral argument held & 12.6 & 19.1 & 2.9 & 47.2 \\
\hline Full judicial opinion & 34.6 & 55.7 & 3.8 & 60.7 \\
\hline Reply brief filed & 15.6 & 26.3 & - & - \\
\hline Private attorney & 5.6 & 6.9 & 3.6 & 7.9 \\
\hline Public attorney & 52.0 & 73.3 & 20.8 & 52.8 \\
\hline Pro se & 7.8 & 4.9 & 11.9 & 7.9 \\
\hline (unknown represent.) & 34.7 & 14.9 & 63.6 & 31.5 \\
\hline Anders case & 6.5 & 11.0 & 0.0 & 0.0 \\
\hline$N$ & 3,505 & 2,080 & 1,425 & 89 \\
\hline
\end{tabular}

SOURCE: Survey of State Court Criminal Appeals, supra note 2.

Table 3A compares rates for merits review and favorable decisions in first appeals of right, by independent variable. For example, cases with sentence claims fared better $(20.5 \%$ decided favorably) than those that did not have this type of claim or were missing this information (10.6\% decided favorably). Assault, drug possession, and public-order offenses had lower rates of merits review and favorable decisions. Counseled defendants fared much better than pro se appellants, and those who retained attorneys secured merits review and favorable decisions at a higher rate than appellants with publicly funded attorneys. Cases with oral arguments, full opinions, or reply briefs succeeded at a higher rate than cases that lacked these features, and cases with Anders-type statements were less likely to receive a favorable decision $(4.0 \%$ versus $16.2 \%)$. Cases heard by courts with elected judges were more likely to receive a favorable decision (15.3\% versus $14.5 \%)$, however. Defense appeals in California secured 
favorable decisions at a higher rate than other states $(19.3 \%$ versus $14.1 \%$ ), while defense appeals in Florida fared worse than in other states $(10.4 \%$ versus $15.5 \%)$.

TABLE 3A: INDEPENDENT VARIABLES BY KEY OUTCOMES, FIRST APPEALS OF RIGHT

\begin{tabular}{|c|c|c|c|c|}
\hline & $\begin{array}{l}(1) \\
\% \text { cases } \\
\text { with } \\
\text { variable } \\
\text { receiving } \\
\text { merits } \\
\text { review }\end{array}$ & $\begin{array}{c}(2) \\
\% \text { cases } \\
\text { w/o } \\
\text { variable } \\
\text { receiving } \\
\text { merits } \\
\text { review }\end{array}$ & $\begin{array}{c}\text { (3) } \\
\% \text { cases } \\
\text { with } \\
\text { variable } \\
\text { receiving } \\
\text { decision } \\
\text { favoring D }\end{array}$ & $\begin{array}{c}(4) \\
\% \text { cases } \\
\text { w/o } \\
\text { variable } \\
\text { receiving } \\
\text { decision } \\
\text { favoring D }\end{array}$ \\
\hline \multicolumn{5}{|l|}{$\begin{array}{l}\text { Independent Variables: } \\
\text { Appeal from: }\end{array}$} \\
\hline Conviction (alone) & 97.2 & 83.9 & 12.3 & 17.2 \\
\hline Sentence (included) & 94.1 & 87.5 & 20.5 & 10.6 \\
\hline (unknown/missing) & 35.3 & 95.8 & 1.6 & 16.2 \\
\hline \multicolumn{5}{|l|}{ Crime type: } \\
\hline Murder/vol. manslau. & 93.0 & 89.9 & 14.1 & 15.0 \\
\hline Sex offense & 92.6 & 90.0 & 16.7 & 14.6 \\
\hline Robbery & 91.7 & 90.2 & 12.6 & 15.1 \\
\hline Assault & 88.6 & 90.7 & 13.1 & 15.2 \\
\hline Burglary & 93.9 & 90.1 & 16.0 & 14.8 \\
\hline Drug trafficking & 91.9 & 90.1 & 18.0 & 14.4 \\
\hline Drug possession & 82.1 & 90.8 & 12.8 & 15.0 \\
\hline Public order & 89.5 & 90.4 & 11.6 & 15.2 \\
\hline Court order violation & 82.1 & 90.5 & 28.6 & 14.7 \\
\hline (unknown felony) & 6.7 & 90.9 & 0.0 & 15.0 \\
\hline \multicolumn{5}{|l|}{ Claim included in brief: } \\
\hline Charge, statute, venue & 98.5 & 89.5 & 21.1 & 14.2 \\
\hline Plea related & 91.7 & 90.2 & 14.7 & 14.9 \\
\hline Other pretrial & 95.9 & 98.7 & 24.0 & 13.8 \\
\hline Discovery, prosec. miscon. & 97.9 & 89.6 & 17.0 & 14.6 \\
\hline Evidence suppression & 98.6 & 89.1 & 15.8 & 14.7 \\
\hline Insufficient evidence & 98.7 & 86.9 & 16.9 & 14.0 \\
\hline Other evidence, confront. & 98.6 & 88.3 & 20.8 & 13.4 \\
\hline Judge, jury & 99.2 & 88.5 & 19.4 & 13.9 \\
\hline Other trial issue & 98.1 & 89.3 & 23.0 & 13.7 \\
\hline Sentence & 97.4 & 87.3 & 21.7 & 11.9 \\
\hline Counsel & 97.7 & 89.3 & 16.9 & 14.6 \\
\hline \multicolumn{5}{|l|}{ Court factors: } \\
\hline Elected judges & 88.9 & 91.6 & 15.3 & 14.5 \\
\hline CA state & 96.5 & 89.3 & 19.3 & 14.1 \\
\hline FL state & 90.8 & 90.3 & 10.4 & 15.5 \\
\hline Workload & 一 & - & - & - \\
\hline \multicolumn{5}{|l|}{ Process \& advocacy factors: } \\
\hline Oral argument held & 99.8 & 88.1 & 24.4 & 12.6 \\
\hline Full judicial opinion & 99.7 & 78.5 & 21.5 & 6.5 \\
\hline
\end{tabular}




\begin{tabular}{|c|c|c|c|c|}
\hline & $\begin{array}{l}(1) \\
\% \text { cases } \\
\text { with } \\
\text { variable } \\
\text { receiving } \\
\text { merits } \\
\text { review }\end{array}$ & $\begin{array}{c}(2) \\
\% \text { cases } \\
\text { w/o } \\
\text { variable } \\
\text { receiving } \\
\text { merits } \\
\text { review }\end{array}$ & $\begin{array}{c}(3) \\
\% \text { cases } \\
\text { with } \\
\text { variable } \\
\text { receiving } \\
\text { decision } \\
\text { favoring D }\end{array}$ & $\begin{array}{c}(4) \\
\% \text { cases } \\
\text { w/o } \\
\text { variable } \\
\text { receiving } \\
\text { decision } \\
\text { favoring D }\end{array}$ \\
\hline Reply brief filed & 99.6 & 87.0 & 26.1 & 10.8 \\
\hline Private attorney & 92.4 & 90.2 & 18.8 & 14.6 \\
\hline Public attorney & 93.6 & 81.3 & 16.9 & 9.4 \\
\hline Pro se & 52.9 & 92.3 & 2.9 & 15.5 \\
\hline (unknown represent.) & 85.5 & 91.2 & 7.1 & 16.2 \\
\hline Anders case & 91.2 & 90.2 & 4.0 & 16.2 \\
\hline$N$ & 2,080 & 2,080 & 2,080 & 2,080 \\
\hline
\end{tabular}

SourCE: Survey of State Court Criminal Appeals, supra note 2.

Table 3B reports similar comparisons for discretionary appeals decided by courts of last resort. Some differences were consistent with first level of right appeals. For example, among cases granted review, those with sentencing claims fared better $(60.9 \%$ had favorable decision) than cases that challenged the conviction alone $(49.0 \%)$ or were missing this information (11.8\% favorable). Also, cases decided by courts with elected judges were more likely to favor defendants than those without $(54.6 \%$ versus $39.3 \%)$.

In contrast to the set of first level of right appeals, however, defendants who appealed to California's Supreme Court secured a favorable decision at a much lower rate than defendants who appealed to other states' high courts: $2.8 \%$ compared to $8.6 \%$ were granted review, and only $12.5 \%$ received favorable decisions among granted cases as compared to $52.1 \%$. Also, appellants represented by publicly funded counsel succeeded at a higher rate than those who retained private counsel $(61.7 \%$ versus $28.6 \%)$. 

TABLE 3B: INDEPENDENT VARIABLES BY KEY OUTCOMES,
DISCRETIONARY COLR

\begin{tabular}{|c|c|c|c|c|}
\hline . & $\begin{array}{c}(1) \\
\% \text { cases } \\
\text { with } \\
\text { variable } \\
\text { granted } \\
\text { leave }\end{array}$ & $\begin{array}{c}(2) \\
\% \text { cases w/o } \\
\text { variable } \\
\text { granted } \\
\text { leave }\end{array}$ & $\begin{array}{c}(3) \\
\% \text { cases } \\
\text { granted } \\
\text { review with } \\
\text { variable } \\
\text { decision } \\
\text { favoring D }\end{array}$ & $\begin{array}{c}(4) \\
\% \text { cases } \\
\text { granted } \\
\text { review w/o } \\
\text { variable } \\
\text { decision } \\
\text { favoring D }\end{array}$ \\
\hline \multicolumn{5}{|l|}{$\begin{array}{l}\text { Independent } \\
\text { Variables: } \\
\text { Appeal from: }\end{array}$} \\
\hline Conviction (alone) & 23.0 & 3.3 & 49.0 & 40.0 \\
\hline Sentence (included) & 11.6 & 5.4 & 60.9 & 39.4 \\
\hline (unknown/missing) & 1.7 & 17.5 & 11.8 & 52.8 \\
\hline \multicolumn{5}{|l|}{ Crime type: } \\
\hline Murder/vol. manslau. & 6.4 & 6.2 & 25.0 & 48.1 \\
\hline Sex offense & 11.3 & 5.6 & 66.7 & 39.4 \\
\hline Robbery & 9.6 & 6.0 & 63.6 & 42.3 \\
\hline Assault & 3.3 & 6.6 & 40.0 & 45.2 \\
\hline Drug trafficking & 15.7 & 5.5 & 58.8 & 41.7 \\
\hline Drug possession & 13.6 & 5.9 & 37.5 & 45.7 \\
\hline \multicolumn{5}{|l|}{ Claim included in brief: } \\
\hline Charge, statute, venue & 47.1 & 5.8 & 75.0 & 42.0 \\
\hline Other pretrial & 62.5 & 5.6 & 50.0 & 44.3 \\
\hline Evidence suppression & 86.4 & 5.0 & 36.8 & 47.1 \\
\hline Insufficient evidence & 47.1 & 5.3 & 68.8 & 39.7 \\
\hline Other evid., confront. & 60.0 & 5.5 & 41.7 & 45.5 \\
\hline Judge, jury & 65.0 & 5.4 & 61.5 & 42.1 \\
\hline Other trial issue & 73.3 & 5.5 & 63.6 & 42.3 \\
\hline Sentence & 20.0 & 6.1 & 50.0 & 44.7 \\
\hline Counsel & 55.6 & 5.9 & 80.0 & 42.9 \\
\hline \multicolumn{5}{|l|}{ Court factors: } \\
\hline Elected judges & 6.7 & 6.0 & 54.6 & 39.3 \\
\hline CA state & 2.8 & 8.6 & 12.5 & 52.1 \\
\hline Workload & - & - & - & - \\
\hline \multicolumn{5}{|l|}{ Process \& advocacy: } \\
\hline Private attorney & 13.7 & 3.7 & 28.6 & 46.3 \\
\hline Public attorney & 15.8 & 3.7 & 61.7 & 26.2 \\
\hline (unknown represent.) & 3.1 & 11.8 & 32.1 & 50.8 \\
\hline$N$ & 1,425 & 1,425 & 89 & 89 \\
\hline
\end{tabular}

SoURCE: Survey of State Court Criminal Appeals, supra note 2.

\section{B. Regression Results}

While our descriptive findings hint at possible relations between some aspects of appeals and the prospects for success, more formal 
modeling and analyses are necessary to assess whether those relations withstand more rigorous empirical testing.

\section{First Appeals of Right}

For our analysis of first appeals of right, we modeled two measures of defendant success-receiving merits review (Table 4) and receiving a favorable outcome (Table 5).

Merits review. Courts reviewed claims on the merits in over $90 \%$ of the cases; in only $10 \%$ of the cases was the appeal either withdrawn or dismissed without reaching the merits. Given the skewed distribution of our dependent variable, Table 4 presents results from a rare events model.

Both convictions-only and sentence-included appeals were significantly less likely to be dismissed or withdrawn than cases missing this information, possibly because dismissal or withdrawal occurred before the briefing that would have supplied this information. Two crime types, drug possession and court order violations, were significantly more likely than other crime types to be withdrawn or dismissed. Among the array of potential legal claims, claims relating to guilty pleas, other pretrial matters, and discovery issues increased the likelihood of withdrawal or dismissal rather than merits review, while claims involving insufficient evidence, the sentence, and "other" trial matters increased the prospects for merits review. California appellants were less likely than appellants from other states to receive merits review. As expected, presence of an oral argument, full opinion, or reply brief was associated with increased likelihood of merits review. Finally, the presence of an Anders-type brief increased the probability of receiving merits review. 
TABle 4: RARe Events Model, Merits Review: First APPEAL OF RIGHT

\begin{tabular}{lll}
\hline & Rare events & $($ s.e. $)$ \\
\hline Def. received merits review & & \\
Appeal from: & & \\
Conviction (alone) & $1.59^{* *}$ & $(0.22)$ \\
Sentence (included) & $1.14^{* *}$ & $(0.22)$ \\
Crime type: & & \\
Murder/vol. manslaughter & -0.13 & $(0.24)$ \\
Sex offense & 0.02 & $(0.20)$ \\
Robbery & 0.32 & $(0.24)$ \\
Assault & -0.23 & $(0.23)$ \\
Burglary & 0.16 & $(0.21)$ \\
Drug trafficking & -0.25 & $(0.22)$ \\
Drug possession & $-0.50 * *$ & $(0.18)$ \\
Public order & -0.18 & $(0.26)$ \\
Court order violation & $-0.73^{*}$ & $(0.29)$ \\
Claim included in brief: & & \\
Charge, statute, venue & 0.32 & $(0.24)$ \\
Plea related & $-0.32 * *$ & $(0.10)$ \\
Other pretrial & $-0.54 * *$ & $(0.15)$ \\
Discovery, prosec. & $-0.43^{* *}$ & $(0.14)$ \\
Evidence suppression & 0.48 & $(0.32)$ \\
Insufficient evidence & $0.51^{* *}$ & $(0.18)$ \\
Other evidence, confront. & 0.24 & $(0.17)$ \\
Judge, jury & 0.32 & $(0.23)$ \\
Other trial issue & $0.59 * *$ & $(0.18)$ \\
Sentence & $0.61 * *$ & $(0.10)$ \\
Counsel & 0.04 & $(0.26)$ \\
Court factors: & & \\
Elected judges & -0.24 & $(0.23)$ \\
CA state & $-0.62^{* *}$ & $(0.16)$ \\
FL state & 0.07 & $(0.17)$ \\
Process \& advocacy: & & \\
Oral argument held & $-2.57^{* *}$ & $(0.18)$ \\
Full judicial opinion & $1.51^{* *}$ & $(0.22)$ \\
Reply brief filed & $0.93^{* *}$ & $(0.22)$ \\
Private attorney & 0.02 & $(0.21)$ \\
Public attorney & 0.25 & $(0.13)$ \\
Pro se & -0.55 & $(0.37)$ \\
Anders case & $0.36 *$ & $(0.16)$ \\
Constant & $-1.00^{* *}$ & $(0.30)$ \\
$N$ & & \\
Log likelihood & & \\
\hline
\end{tabular}

NOTES: We report results from a rare events regression model of defendant success in receiving a merits review with initial appeals to courts with mandatory jurisdiction. Robust standard errors (clustered on the state level) are in parentheses. ${ }^{*} p<0.05 ;{ }^{*} p<0.01$. We estimated the models using the "cloglog" command in Stata (v.14.2).

SOURCE: Survey of State Court Criminal Appeals, supra note 2. 
Favorable defense outcome. Only $14.9 \%$ of the first appeals of right produced a favorable outcome for the defendant. Our hypothesis that defendants would be comparatively more successful in obtaining appellate relief from sentencing errors was consistent with the finding that relief was significantly more likely when a sentence claim was briefed. ${ }^{40}$ As expected, the presence of an Anders brief decreased the likelihood of success, while the presence of an oral argument, a full judicial opinion, or a reply brief increased that likelihood.

Only two claim-related variables achieved statistical significance. Cases raising "other trial" errors were not only more likely to be reviewed on the merits, they were also associated with a higher likelihood of a favorable decision for the defense. By contrast, although cases raising claims of "other pretrial error" were less likely to receive merits review, if not dismissed or withdrawn, they were more likely to obtain a favorable decision.

One factor that in descriptive analyses corresponded with lower relief rates-Florida appeals-correlates with a greater likelihood of relief in the regression model. The presence of an attorney-whether it was a public or private attorney -increased a defendant's prospects for a favorable outcome, as it did in simple comparisons. In contrast, however, pro se defendants were neither more nor less likely to receive a favorable outcome when compared to all other defendants who were not pro se (that is, defendants with attorneys along with the $14.9 \%$ of the sample that lacks information on legal counsel).

\section{TABLE 5: RARE EVEnTS MODEL, DECISION FAVORING DEFENDANT: FIRST APPEAL OF RIGHT}

\begin{tabular}{lll}
\hline & $\begin{array}{l}\text { Rare } \\
\text { events }\end{array}$ & (s.e.) \\
\hline $\begin{array}{l}\text { Outcome favored def. } \\
\text { Appeal from: }\end{array}$ & & \\
$\quad$ Conviction (alone) & 0.86 & $(0.51)$ \\
$\quad$ Sentence (included) & $1.44 * *$ & $(0.46)$ \\
Crime type: & & \\
Murder/vol. manslaughter & -0.60 & $(0.32)$ \\
Sex offense & -0.28 & $(0.29)$ \\
Robbery & -0.39 & $(0.32)$ \\
Assault & -0.37 & $(0.22)$ \\
Burglary & -0.17 & $(0.32)$ \\
Drug trafficking & 0.11 & $(0.25)$ \\
Drug possession & -0.12 & $(0.28)$ \\
\hline
\end{tabular}

40. Because our model examines claims raised in briefs rather than claims discussed in opinions (data missing in most cases), it shows only that briefing the claim is associated with a greater likelihood of relief, not that the sentencing claims themselves were granted. 


\begin{tabular}{|c|c|c|}
\hline & $\begin{array}{l}\text { Rare } \\
\text { events }\end{array}$ & (s.e.) \\
\hline Public order & .0 .39 & $(0.27)$ \\
\hline Court order violation & 0.18 & $(0.33)$ \\
\hline \multicolumn{3}{|l|}{ Claim included in brief: } \\
\hline Charge, statute, venue & 0.01 & $(0.20)$ \\
\hline Plea related & 0.34 & $(0.26)$ \\
\hline Other pretrial & $0.37 * *$ & $(0.14)$ \\
\hline Discovery, prosec. & -0.05 & $(0.18)$ \\
\hline Evidence suppression & 0.04 & $(.019)$ \\
\hline Insufficient evidence & 0.05 & $(0.09)$ \\
\hline Other evidence, confront. & 0.31 & $(0.20)$ \\
\hline Judge, jury & 0.10 & $(0.13)$ \\
\hline Other trial issue & $0.38 *$ & $(0.15)$ \\
\hline Sentence & 0.20 & $(0.16)$ \\
\hline Counsel & -0.14 & $(0.13)$ \\
\hline \multicolumn{3}{|l|}{ Court factors: } \\
\hline Elected & 0.17 & $(0.20)$ \\
\hline CA state & -0.15 & $(0.17)$ \\
\hline FL state & $0.75 * \star$ & $(0.23)$ \\
\hline Workload & -0.00 & $(0.00)$ \\
\hline \multicolumn{3}{|l|}{ Process \& advocacy factors: } \\
\hline Oral argument held & 0.53 * & $(0.21)$ \\
\hline Full judicial opinion & $0.95 * *$ & $(0.34)$ \\
\hline Reply brief filed & $0.54 * *$ & $(0.14)$ \\
\hline Private attorney & $0.89 * *$ & $(0.27)$ \\
\hline Public attorney & $0.88 * \star$ & $(0.21)$ \\
\hline Pro se & .0 .29 & $(0.27)$ \\
\hline Anders case & $-1.14 * *$ & $(0.26)$ \\
\hline Constant & $-4.57 * \star$ & $(0.60)$ \\
\hline$N$ & 2,080 & \\
\hline Log likelihood & -740.06 & \\
\hline
\end{tabular}

NOTES: We report results from a rare events regression model of defendant success with initial appeals to courts with mandatory jurisdiction. The dependent variable is whether the appellate court outcome favored the defendant (a favorable outcome being anything less than a full affirmance, a withdrawal, or dismissal). Robust standard errors (clustered on the state level) are in parentheses. ${ }^{*} p<0.05 ;{ }^{* *} p<0.01$. We estimated the models using the "cloglog" command in Stata (v.14.2).

SouRCE: Survey of State Court Criminal Appeals, supra note 2.

\section{Courts of Last Resort}

Our analysis of discretionary appeals to courts of last resort includes three models. The first (Table 6) examines the likelihood of receiving leave to appeal from among all cases disposed by these courts. Table 7 presents results of models examining the likelihood of a favorable outcome, the first model from among all cases decided and the second model for the much smaller subset of those cases granted review. 
These models include fewer variables than the of right appeals models, as fewer appeals are considered and some of the independent variables lacked the necessary variation for inclusion in the models.

TABLE 6: RARE EventS MODEL, LEAvE TO APPEAL GRANTED: COURTS OF LAST RESORT

\begin{tabular}{|c|c|c|}
\hline & $\begin{array}{l}\text { Rare } \\
\text { events }\end{array}$ & (s.e.) \\
\hline \multicolumn{3}{|l|}{ Def. appeal granted } \\
\hline \multicolumn{3}{|l|}{ Appeal from: } \\
\hline Conviction (alone) & $2.28^{* *}$ & $(0.80)$ \\
\hline Sentence (included) & 1.63 & $(0.86)$ \\
\hline \multicolumn{3}{|l|}{ Crime type: } \\
\hline Murder/vol. manslaughter & -0.13 & $(0.49)$ \\
\hline Sex offense & 0.49 & $(0.62)$ \\
\hline Robbery & 0.63 & $(0.77)$ \\
\hline Assault & -0.76 & $(0.67)$ \\
\hline Drug trafficking & 1.06 * & $(0.42)$ \\
\hline Drug possession & 0.63 & $(0.63)$ \\
\hline \multicolumn{3}{|l|}{ Claim included in brief: } \\
\hline Charge, statute, venue & -0.15 & $(0.72)$ \\
\hline Other pretrial & 2.70 * & $(1.21)$ \\
\hline Evidence suppression & $2.62 * *$ & $(0.56)$ \\
\hline Insufficient evidence & 0.83 & $(0.62)$ \\
\hline Other evidence, confront. & 1.40 * & (0.59) \\
\hline Judge, jury & 2.00 * & $(0.88)$ \\
\hline Other trial issue & 1.53 & (1.01) \\
\hline Sentence & -1.56 & $(2.35)$ \\
\hline Counsel & 2.25 * & $(1.06)$ \\
\hline \multicolumn{3}{|l|}{ Court factors: } \\
\hline Elected judges & $-1.32 *$ & $(0.65)$ \\
\hline CA state & 1.23 & (3.83) \\
\hline Workload & -0.00 & $(0.00)$ \\
\hline \multicolumn{3}{|l|}{ Process \& advocacy: } \\
\hline Private attorney & 0.34 & $(0.63)$ \\
\hline Public attorney & $0.86 * *$ & $(0.32)$ \\
\hline Constant & $-4.18 * *$ & (1.15) \\
\hline$N$ & 1,425 & \\
\hline Log likelihood & -181.59 & \\
\hline
\end{tabular}

NoTES: We report results from a rare events regression model of defendant success with securing a discretionary appeal with secondary appeals court. The dependent variable is whether the appellate court granted the defendant's leave to appeal. Robust standard errors (clustered on the state level) are in parentheses. ${ }^{*} p<0.05 ;{ }^{* *} p<0.01$. We estimated the models using the "cloglog" command in Stata (v.14.2).

SoURCE: Survey of State Court Criminal Appeals, supra note 2. 


\section{TABLE 7: RARE Events AND LOGISTIC MODELS, DECISION FAVORING DEFENDANT: COURTS OF LAST RESORT}

\begin{tabular}{|c|c|c|c|c|}
\hline & $\begin{array}{l}\text { Rare } \\
\text { events }\end{array}$ & (s.e.) & $\begin{array}{l}\text { (2) } \\
\text { Logistic, } \\
\text { of appeals } \\
\text { granted }\end{array}$ & (s.e.) \\
\hline \multicolumn{5}{|l|}{$\begin{array}{l}\text { Outcome favored def. } \\
\text { Appeal from: }\end{array}$} \\
\hline Conviction (alone) & 2.23 * & $(0.90)$ & 0.88 & $(1.31)$ \\
\hline Sentence (included) & $1.69 *$ & $(0.82)$ & 0.01 & $(1.53)$ \\
\hline \multicolumn{5}{|l|}{ Crime type: } \\
\hline Murder/vol. manslaughter & -0.24 & $(1.17)$ & -1.35 & (1.68) \\
\hline Sex offense & 1.43 & $(0.88)$ & $3.14 * *$ & (1.15) \\
\hline Robbery & 1.36 & $(0.95)$ & 2.19 & $(1.73)$ \\
\hline Assault & -1.06 & $(1.91)$ & -0.50 & (1.32) \\
\hline Drug trafficking & $2.07 * *$ & $(0.75)$ & 2.93 & (1.99) \\
\hline Drug possession & 1.33 & $(1.00)$ & 2.04 & $(2.39)$ \\
\hline \multicolumn{5}{|l|}{ Claim included in brief: } \\
\hline Charge, statute, venue & 0.73 & $(0.64)$ & 2.58 & $(1.50)$ \\
\hline Evidence suppression & 0.98 & $(0.77)$ & -1.58 & (1.01) \\
\hline Other pretrial & 0.26 & (1.39) & -2.79 & (1.77) \\
\hline Insufficient evidence & 0.97 & (1.05) & -1.83 & (1.28) \\
\hline Other evidence, confront. & -0.59 & $(0.75)$ & $-3.80 *$ & (1.86) \\
\hline Judge, jury & 1.67 & $(1.16)$ & 3.80 & (1.96) \\
\hline Other trial issue & 2.59 * & $(1.02)$ & $4.90 * *$ & (1.68) \\
\hline Sentence & -0.27 & $(2.25)$ & 1.18 & $(2.45)$ \\
\hline Counsel & 2.03 & $(1.07)$ & 0.56 & $(3.09)$ \\
\hline \multicolumn{5}{|l|}{ Court factors: } \\
\hline Elected judges & -0.57 & $(0.65)$ & 1.37 & $(1.12)$ \\
\hline CA state & -2.65 & $(4.38)$ & -0.85 & $(4.46)$ \\
\hline Workload & -0.00 & $(0.00)$ & -0.00 & $(0.00)$ \\
\hline \multicolumn{5}{|l|}{ Process \& advocacy: } \\
\hline Private attorney & -0.28 & $(0.68)$ & -0.21 & (1.87) \\
\hline Public attorney & $1.52 * *$ & $(0.53)$ & 3.57 * & $(1.70)$ \\
\hline Constant & $-5.51 * \star$ & (1.02) & .3 .25 & $(2.55)$ \\
\hline$N$ & 1,425 & & 89 & \\
\hline Log likelihood & -85.95 & & -31.22 & \\
\hline Psuedo R2 & - & & 0.49 & \\
\hline
\end{tabular}

NOTES: We report results from a rare events and logistic regression models of defendant success with secondary appeals to courts with discretionary jurisdiction. The dependent variable is whether the appellate court outcome favored the defendant (defendant success is construed as something less than a full affirmance and involved upsetting, to some degree, the lower court decision). Model 1 includes all appeals to a state's court of last resort. Model 2 includes only those appeals to a state's court of last resort where the defendant's appeal was granted. Robust standard errors (clustered on the state level) are in parentheses. ${ }^{*} p<0.05 ;{ }^{* *} p<0.01$. We estimated models (1) and (2) using the "cloglog" and "logit" commands in Stata (v.14.2), respectively. SOURCE: Survey of State Court Criminal Appeals, supra note 2. 
Leave to appeal. Table 6 reports results from our model evaluating factors that correlate with success in obtaining leave to appeal. These results should be assessed cautiously as they include information from data in $93.8 \%$ of appeals that the courts of last resort declined to hear, and a large number of those cases were missing information for several of the independent variables. Unlike the lower success of conviction-only challenges in of right appeals (see Table 5), conviction-only challenges increased the probability of the court granting the defendant's leave to appeal, although information about whether the sentence or conviction was challenged was missing from more than $71 \%$ of cases. A number of claims correlated with greater likelihood of receiving review (claims information was available in more than three quarters of the cases), but sentence claims were not among them. Appellants with publicly funded counsel were more successful in securing review in courts of last resort than all other appellants, although $64 \%$ of the cases did not include information on type of representation. As for crime type, information missing from about $32 \%$ of cases, one type of crime-drug trafficking-achieved statistical significance and correlated with a greater chance of securing leave to appeal. Finally, there was a lower likelihood for review in states where judges on a state's court of last resort were selected with some form of election.

Favorable defense outcome. Examining only the $6.2 \%$ of cases that courts of last resort agreed to hear, Table 7 presents two separate models of outcomes favoring defendants. Column 1 presents results drawn from the universe of all appeals decided $(1,425)$ by these courts of last resort. As with results in Table 6, results in Column 1 must be considered with caution as they include information from appeals denied review, most of which were missing information for several of the independent variables. These results nonetheless warrant presentation, as they provide helpful context for the results presented in Column 2. The results in Column 2 reflect only those eighty-nine appeals the court agreed to review and, as a consequence, statistical power is reduced.

Pursuing "other" trial issues (a category that includes, e.g., competency, mistrial, and joinder issues) on appeal correlated with an increased probability of an outcome favoring a defendant under both models. Additionally, a publicly funded attorney increased the probability of a defendant-favorable outcome. Aside from these two robust findings, most factors that had achieved statistical significance under the rare events model of the entire universe of appeals fell out of significance in the model that examined only the eighty-nine cases that courts of last resort agreed to hear. For example, among the various 
crime types, drug trafficking was associated with a higher likelihood of favorable decision when all appeals were considered but was replaced by sex offenses in the pool of cases accepted for review.

\section{Discussion}

\section{Comparison to Prior Studies}

Owing to differences in data sources, coding conventions, and modeling, comparing results across various studies invites some interpretative risk. ${ }^{41}$ These important methodological differences notwithstanding, however, the rate at which defendants succeed with their criminal appeals appears to have dropped over the past decades. The $14.9 \%$ favorable decision rate in first appeals of right that we found (Table 2) is somewhat lower than the rates reported using samples from earlier periods, but fairly consistent with the findings of the most recent single-state study examining decisions from 2012 and $2013 .{ }^{42}$ In courts of last resort, among all cases decided in our sample, the rate of favorable decisions $(2.8 \%$; Table 2) was lower than rates found by studies of decisions from earlier periods, as was the rate of favorable decisions among cases granted review (44.9\%; Table 2)..$^{43}$ Consistent with prior work, we also found that including a challenge to the sentence in a first appeal of right is associated with a significantly higher likelihood of success. ${ }^{44}$

\section{Sentencing Challenges and Sentencing Claims}

We initially hypothesized that because sentencing error is comparatively easier and cheaper to correct than conviction error, an appeal challenging a sentence would generate higher rates of relief than an appeal that challenges only the underlying criminal conviction. As Table 5 suggests, results from our analyses of first appeals of right are consistent with this hypothesis. In the court of last resort context, however, results presented in Table 6 imply there is a greater probability that a high court will grant review when an appeal challenges solely the underlying conviction. The results in Table 7 suggest that a challenge to the sentence does not significantly increase

41. See, e.g., CHAPPER \& HANSON, supra note 5; Eisenberg \& Miller, supra note 3; King, supra note 17 (collecting estimates of success rates in noncapital state postconviction proceedings).

42. See, e.g., ChAPPER \& HANSON, supra note 5; Buller, supra note 7, app. C at 242 tbl.1; Foley, supra note 8.

43. See, e.g., HANSON, supra note 4; Eisenberg et al., supra note 3, at 694-97; Eisenberg \& Miller, supra note 3 , at 1468 tbl.1.

44. See, for example, supra note 27. 
the likelihood of a favorable decision once review is granted. Also, despite the higher rates of success for last-resort cases that include a sentencing claim in simple comparisons, in none of the models was the presence of a sentencing claim in the brief associated with a significantly greater (or lesser) likelihood of receiving either review or a favorable decision.

While the mixed results from our study may provide little firm support for our initial hypothesis, it may also be possible to harmonize the results. First, one might discount the findings in Table 6 concerning the decision to grant review as the significance of conviction-only challenges is based on information about what aspect of the judgment was appealed that was missing from more than $70 \%$ of the cases examined. Alternatively, the relative ease of correcting simpler sentencing errors in initial appeals of right may have left for courts of last resort those sentencing claims that are more difficult to resolve in favor of the appellant. Finally, it is also possible that conviction-only appeals more closely fit the selection criteria state high courts use when determining which cases require attention. Wrongful convictions, for example, present one category of egregious error. Moreover, claims affecting the validity of guilt findings may tend to create more division among lower courts than sentencing issues.

\section{Representation and Anders Briefs}

Our results support our initial assumption that counseled appeals will be more successful than pro se appeals. In no context did pro se defendants achieve a comparative advantage over defendants represented by legal counsel. But our results do not support our hypothesis that privately retained counsel will achieve better results than publicly funded counsel. In the court of last resort context, for example, the presence of a publicly funded counsel (defender or appointed) consistently achieved more favorable results for defendants across all three models. Although these findings must be considered with caution (the two last-resort models lacked information about representation in $64 \%$, and $32 \%$ of the cases, respectively), they may contribute to a growing literature finding superior performance of public defender offices as compared to retained counsel, an advantage researchers have attributed to greater expertise, specialization, and other factors. ${ }^{45}$

45. See, e.g., U.S. DEP'T OF JUSTICE, INDIGENT DEFENSE STATISTICS (1999) (finding that publicly financed defense lawyers, combining public defenders and appointed counsel, were slightly more effective than privately retained counsel); Roger A Hanson et al., Effective Adversaries for the Poor, in THE JAPANESE AdVERSARY SySTEM IN CONTEXT 89 (Malcolm M. Feeley 
Anders briefs, as expected, correlated with a reduced likelihood of success in first appeals of right. That Anders briefs increased the likelihood of merits review may seem surprising, but is consistent with the Supreme Court's case law requiring a "full review" of potential claims in such cases. ${ }^{46}$

\section{California and Florida Appeals}

California cases made up the largest portion (15\%) of the first appeals of right subpool and $40 \%$ of the discretionary-last-resort subpool. First appeals of right in California were less likely to receive merits review but no less likely than appeals in other states to receive a favorable decision. Possible explanations for the greater number of dismissals and withdrawals may include the state's requirement that a defendant appealing from a guilty plea first secure certification from the trial judge.

Although simple comparisons illustrate a strikingly low rate of grants of review by the California Supreme Court (Table 3B), once other factors were controlled in the regression models, the likelihood of receiving review in the California Supreme Court was no lower than in other states. Also, once leave was granted by the California Supreme Court, a defendant was no less likely to receive a favorable decision than appellants in other states. The only model suggesting appellants had a comparative disadvantage in the California Supreme Court was the rare-events analysis that included cases denied review.

At a descriptive level, defense appeals to the Florida courts of appeals failed at a higher rate than other states (Table 3A). But once other factors were controlled in the regression models, Florida defendants fared significantly better than those in other states. This suggests that the depressed rate of relief for Florida intermediate

\footnotetext{
\& Setsuo Miyazawa eds., 2002); Buller, supra note 7, at 184-85 (study of Iowa criminal appeals showing "appellate defenders generally perform better than court-appointed lawyers-they win more cases, have fewer procedural and technical problems, seek further review in more cases, and obtain further review more often"); Richard D. Hartley et al., Do You Get What You Pay For? Type of Counsel and Its Effect on Criminal Court Outcomes, 38 J. CRIM. JUST. 1063 (2010) (finding no meaningful differences among various defendant counsel types); Michael A. Roach, Indigent Defense Counsel, Attorney Counsel, and Defendant Outcomes, 16 AM. L. \& ECON. Rev. 577 (2014) (finding that public defenders outperform court-appointed private counsel); J. Thomas Sullivan, Ethical and Aggressive Appellate Advocacy: The "Ethical" Issue of Issue Selection, 80 DENV. U. L. REV. 155, 197 (2002) (describing advantages for appellate public defenders from statewide offices). But see Morris B. Hoffman et al., An Empirical Study of Public Defender Effectiveness: SelfSelection by the "Marginally Indigent," 3 OHIO ST. J. CRIM. L. 223 (2005) (finding, after adjusting for selection bias, that private attorneys outperform public defenders).
}

46. Anders v. California, 386 U.S. 738 (1967). 
appeals in simple comparisons was attributable to the presence of variables other than being from Florida.

\section{Crime Types Generally}

The type of crime appeared not to matter much with a few exceptions. For first appeals of right, drug possession or court order violation appeals were significantly more likely to be dismissed or withdrawn and not reviewed on the merits compared to appeals from other crime types. In courts of last resort, drug trafficking cases were more likely to receive review and, among cases granted review, sex offenses were much more likely to produce relief for a defendant.

\section{Elected Judges, Oral Argument, Opinions, and Reply Briefs}

We hypothesized that, owing to various political pressures, elected judges would be comparatively less inclined to favor defendants in the criminal appeals setting. The method of judicial selection, however, only achieved statistical significance in one of the court of last resort models, and in our expected direction. Specifically, elected justices correlated with a higher likelihood the defendant's appeal would be denied review (Table 6). In all of the other models, including among cases receiving review in those same courts of last resort, the method of judicial selection did not achieve statistical significance. Finally, the presence of oral argument, full opinions, and reply briefs correlated with defense success in first appeals of right.

\section{Claims Generally}

The original forty-nine claim categories are themselves somewhat imprecise and our aggregation of those categories into eleven broader categories reduced precision further. Consequently, findings related to claims raised in these appeals are more speculative than findings regarding factors more easily (and accurately) measured. That said, it is not surprising that cases that included plea-related claims were associated with decreased likelihood of merits review in first appeals of right. It is possible that some defendants realize or decide only after filing an appeal challenging a guilty plea that a successful challenge may actually cost them valuable concessions, leading to a higher rate of withdrawal. Also, cases raising plea issues in California may include appeals from guilty pleas for which the defendant failed to obtain a certification from the trial court.

Cases including claims addressing various pretrial matters and discovery issues may have higher rates of dismissal if some of them 
were filed prematurely. Cases including claims of insufficient evidence, "other" trial matters ${ }^{47}$ or challenging the sentence were all associated with an increased likelihood of merits review as compared to cases that did not include such claims. It remains a possibility that generally counsel is more likely to raise and preserve these particular claims for appeal, as compared to other sorts of claims.

Cases raising "other trial" errors were not only more likely to be reviewed on the merits, they were also associated with a higher likelihood of a favorable decision for the defense in first appeals of right. It is not clear why these particular issues are better candidates for a defense-friendly outcome. Interestingly, although cases raising claims of "other pretrial error" were less likely to be reviewed on the merits, those that were not dismissed or withdrawn were more likely to obtain a favorable decision. ${ }^{48}$

Two of the three court of last resort models (Table 6 and Table 7, Column 1), lack any discernable pattern of significance for the type of claim raised, but for both of these analyses, claims information was missing for more than $80 \%$ of the cases. Among the granted cases, where claims information was known, "other trial" claims emerged as significantly associated with a favorable decision for the defense as well as judge and jury claims and claims about the charge, offense statute, or venue. Notably, "other trial" claims correlated with a favorable decision at both appellate levels.

\section{CONCLUSION}

The NCSC Study of state criminal appeals provides the most comprehensive collection of information on contemporary state criminal appeals available. As is often the case with initial, exploratory empirical analyses, submitting long-held suppositions about state criminal defendants' appeals to data uncovers both expected and unexpected findings.

Our initial analyses of these data reveal an average success rate of $15 \%$ for first appeals of right and less than $3 \%$ for permissive appeals to courts of last resort. Notably, the rates we observed are lower than those found in earlier studies..$^{49}$ Our findings also provide new insights

47. This category combines the dataset's following issue types: "competency," "language," "court interpreter," "joinder," "mistrial," "other trial management," "cumulative error," "set aside verdict," "new trial," "other post-trial motions," and "other trial court error."

48. This category includes the following issue types: "continuance," "dismissal," "other pretrial management," "speedy trial," and "other constitutional."

49. See, e.g., WATERS ET AL., supra note 4, at 1 (estimating that 69,000 state criminal appeals (weighted sample) were filed in 2010). 
into how state courts resolve appeals. As suspected, we found a large proportion of appeals receive summary processing, with no oral argument, opinion, or reply brief. We also found that factors that correlated with relief varied between first appeals of right and last resort discretionary appeals, variation that may reflect in part the differing functions and features that distinguish these two appellate contexts. Further analyses (and additional data) of the systematic differences that emerged in our study are warranted, and we hope that future scholarship will delve more deeply into these distinct criminal appellate contexts. 